\title{
Preventive effect of fermented red ginseng on cisplatin-induced nephrotoxicity mouse
}

\author{
Ja-Kyoung Hyun ${ }^{1} \cdot$ O Jun Kwon ${ }^{2} \cdot J_{0 o}$ Young Lee ${ }^{3} \cdot$ Seong-Soo Roh $^{3} \cdot$ Young-Bae Seo $^{1}$ \\ Cisplatin으로 유도된 신손상 마우스 모델에 대한 발효홍삼의 예방효능
}

현자경 ${ }^{1} \cdot$ 권오준 $^{2} \cdot$ 이주영 $^{3} \cdot$ 노성수 $^{3} \cdot$ 서영 배 $^{1}$

Received: 3 February 2016 / Accepted: 3 March 2016 / Published Online: 30 June 2016

(C) The Korean Society for Applied Biological Chemistry 2016

\begin{abstract}
Red ginseng is known to have many beneficial effects. Cisplatin, an effective antineoplastic drug, can cause many side effects like irreversible sensorineural hearing loss and serious tinnitus in humans. This study is aimed to reduce a cisplatin's side effect, nephrotoxicity by fermentated korean red ginseng. Korea ginseng was produced by steaming and dring and fermentation. And mice were divided into 4 groups- (A) normal mice, (B) Vehicle treated cisplatin mice, (C) RG0F0-treated cisplatin mice, (D) RG8F3-treated cisplatin mice. C and D groups were feed each material $200 \mathrm{mg} / \mathrm{kg} /$ day during 4 days. And cisplatin $20 \mathrm{mg} / \mathrm{kg}$ injected to B, C, and D groups as abdominal injection. After $24 \mathrm{~h}$, blood sample was collected. The kidneys were harvested for histological, immuno histochemical and western blot analysis. 1,1-diphenyl-2-picrylhydrazyl (DPPH) and 2,2'-azinobis-3-ethylbenzothiazoline-6-sulfonic acid (ABTS) radical scavenging activity was depended on steaming hours. RG0F0 and RG8F3 (ginseng- $8 \mathrm{~h}$
\end{abstract}

Young-Bae Seo $(\bowtie)$

E-mail: genin@dju.ac.kr

${ }^{1}$ College of Korean Medicine, Daejeon University, 62 Daehak-ro, Dong-gu, Daejeon 34520, Republic of Korea

${ }^{2}$ Gyeongbuk Regional industry Evaluation, Daegyeong Institute for Regional Program Evaluation, 27, Sampung-ro, Gyeongsan-si, Gyeongsangbuk-do 38542, Republic of Korea

${ }^{3}$ College of Korean Medicine, Daegu Haany University, 64 Gil, 25 Suseongro, Suseong-gu, Daegu 42158, Republic of Korea

This is an Open Access article distributed under the terms of the Creative Commons Attribution Non-Commercial License (http://creativecommons. org/licenses/by-nc/3.0/) which permits unrestricted non-commercial use, distribution, and reproduction in any medium, provided the original work is properly cited. steamed and fermented by Saccharomyces cerevisiae) were showed antioxidants effect in DPPH and ABTS radical scavenging activity. Component amounts according to steaming hours. $8 \mathrm{~h}$ steamed red ginseng had the most ingredients of ginsenoside. Treatments with RG8F3 reduced cisplatin-induced nephrotoxicity in the mice resulting in increase of GSH and decrease of ROS, BUN, creatinine, and inflammatory mediators. This result seems to be involved with the restriction of the inflammation in the kidney. Therefore, fermented red ginseng might have therapeutic efficacy in reduce kidney injury induced by cisplatin treatment.

Keywords Anti-oxidation $\cdot$ Cisplatin $\cdot$ Fermentation $\cdot$ Nephrotoxicity $\cdot$ Red Ginseng

\section{서 론}

암은 1983년 이후 현재까지 우리나라 주요 사망원인 중 1 위를 기록하고 있다. 현재 암을 않고 있는 환자는 약 100 만명 가량 이고 새롭게 암 진단을 받는 사람도 22 만명 이상으로 그 수는 점차 증가하고 있는 추세이다(Jung 등, 2015). 최근에는 암의 치 료법이 발달하여 치료율이 매우 좋아졌지만 많은 항암제가 암 조직과 정상조직에 대한 선택성이 없기 때문에 오심, 구토, 탈 모, 피부 및 손톱 등의 변색, 점막염, 신경계 부작용, 신장 부 작용 등도 함께 일어나게 된다(Yoon 2008).

Cisplatin (Cis-diamine dichloroplatinum (II))은 백금 원자에 2 개의 염소와 암모니아가 배위된 화합물로써 암세포의 DNA와 결합하여, 암세포의 분열을 억제하여 항암작용을 나타낸다고 알 려져 있다. 임상적으로 항암활성이 매우 강한 물질로서 고환암, 방광암, 전립선암, 난소암, 두경부암, 폐암, 식도암, 위암, 자궁 
경부암 등 광범위한 항암 치료에 사용되며(Krarup-Hansen 등, 2007), 부작용으로는 호흡기계, 소화기계, 신장계, 혈액계, 청각 계 등 여러 부작용이 있으나 신장손상이 가장 대표적이다 (Nicolao와 Giometto 2003).

Cisplatin으로 인한 신손상을 줄이기 위해 이뇨제 투여와 함 께 수화요법(hydration)은 이미 임상치료의 표준요법으로 많이 쓰이고 있으며 이 요법은 신독성, 신경독성, 골수 억제 등을 감 소시킨다(Ozols 등, 1984; Gandara 등, 1989). 또한 sodium thiosulfate (Howell과 Taetle 1980), WR-2721 (amifostine ${ }^{\mathrm{TM}}$ ) (Glover 등, 1989), glutathione (Oriana 등, 1987), Procain (Ahn 등, 2007) 등을 이용한 독성 저하 방법도 쓰이고 있다. 보 정방암탕(Ju 등, 2013), 영지버섯(Kim 등, 2003), 오미자(Park과 Choung 1998), 산조인(Kim과 $\operatorname{Kim} 2014)$ 등의 한약재를 투여 했을 때에도 신장독성을 줄일 수 있다고 나타났다.

또한 cisplatin으로 인한 급성 신부전시 신장 손상은 세포 내 산 화스트레스에 의한 과잉 생성된 활성산소(reactive oxygen species) 에 의해 유발되는데(Sutton과 Molitoris 1998), 이를 줄이기 위해 superoxide dismutase (Davis 등, 2001), 비타민 C, 비타민 E (Appenroth 등, 1997), selenium (Naziroglu 등, 2004), melatonin (Parlakpinar 등, 2002) 등 다양한 종류의 항산화제도 사용된다.

본 연구에서 쓰인 홍삼은 활성산소를 감소시킴으로써, 항암 제로 인한 구토, 두통, 급성 신부전, 신장 독성 등의 부작용을 줄여주는 것으로 보고되어 있다(Baek 등, 2006).

홍삼(紅氽)이란 인삼(Panax ginseng C.A. Meyer)을 증기나 그 밖의 방법으로 쪄서 익혀 말린 것으로서 담적갈색, 담황갈 색, 다갈색 또는 농다갈색의 색상을 띠는 것으로서(Nam 2005), 수삼을 찌고 말리는 과정에서 수삼보다 ginsenoside의 함량이 높아지고 새로운 ginsenoside도 생성되면서 각종 약리 효능을 갖게 된다(Nishijo 등, 2004).

홍삼은 복용 후 장내에서 개개인이 가지고 있는 장내 미생물 에 의해 $\mathrm{G}-\mathrm{Rh} 2$, compound $\mathrm{K}$ 등의 대사물로 전환된 후, 흡수 되어 해당 약리작용을 나타내게 되는데(Hasegawa 등, 1997), 개 개인의 장내 환경과 미생물의 종류는 다르기 때문에 홍삼이 일 정하게 분해, 흡수되지 않는다(Han 등, 2012). 그러나 외부에서 발효를 한번 거친 추출물은 섭취하면 흡수가 더욱 좋아지기 때 문에 $(\mathrm{Kim}$ 등, 2007), 홍삼을 발효하여 섭취하게 된다면 효능이 더욱 좋아짐을 볼 수 있다(Park 등, 2003).

본 연구에서는 홍삼의 항산화 효과를 바탕으로 발효 홍삼을 섭취한 마우스 모델에 cisplatin을 투여하였을 때, 신손상이 억 제되는 유의한 결과를 얻게 되었으므로 이를 보고하는 바이다.

\section{재료 및 방법}

\section{실험재료}

본 연구에서 사용된 홍삼은 경기도 여주에서 재배된 6년근 수 삼을 2013년 10월, 직접 수매하여 사용하였다.

\section{시약}

홍삼 발효를 위해 미생물의 배양에 사용된 시약은 모두 Difco (Difco Laboratory, Detroit, MI, USA) 제품을 사용하였으며, 전 처리에 사용된 효소혼합액은 한국 화학 연구원 융합 화학 연구
팀에서 제공한 Cellulclast, HTec2, Amyloglucosidase 등의 1:1:1 혼합액을 사용하였다. 발효 균주는 F1: Leuconostoc mesenteroides, F2: Lactobacillus sp. MEI 823, F3: Saccharomyces cerevisiae, F4: Lactobacillus paracasei를 사용하였다. 1,1-diphenyl2-picrylhydrazyl (DPPH)와 2,2'-azinobis-3-ethyl-benzothiazoline6-sulfonic acid (ABTS)는 Sigma Aldrich (St. Louis, MO, USA)에서 구입하였고, nitrocellulose membranes는 Amersham $\mathrm{GE}$ Healthcare (Little. Chalfont, $\mathrm{UK}$ )에서 구입하였다. Phenylmethylsulfonyl fluoride (PMSF), superoxide dismutase 1 (SOD-1), catalase, glutathione peroxidase (GPx), nuclear factorkappa B (NF-кB p65), nuclear factor-erythroid 2-related factor 2 (Nrf2), heme oxygenase-1 (HO-1), inducible nitric oxide synthase (iNOS), cyclooxygenase-2 (COX-2), tumor necrosis factor alpha (TNF- $\alpha$ ), interleukin-6 (IL-6), Histone, $\beta$-actin과 2차 항체는 Santa Cruz Biotechnology (Santa Cruz, CA, USA)로부터 구입하였으며, protease inhibitor mixture, dimethyl sulfoxide, ethylenediaminetetraacetic acid는 Wako Pure Chemical Industries, Ltd. (Osaka. Japan)에서 구입하였다. cis-Diammineplatinum (II) dichloride는 Sigma-Aldrich에서, blood urea nitrogen (BUN)과 creatinine assay kit는 아산제약주식회사 (Hwaseong, Korea)에서 구입하였다. 또한, 2,7-Dichlorofluorescein diacetate (DCFH-DA)는 Molecular Probes (Eugene, OR, USA) 에서 enhanced chemiluminescence (ECL) Western Blotting Detection Reagents는 GE Healthcare (Piscataway, NJ, USA) 로부터 구입하여 사용하였다. 단백질 정량을 위한 $\mathrm{BCA}$ protein assay kit는 Thermo Scientific (Rockford, IL, USA)에서 구입 하였다. 미생물의 배양에 사용된 시약은 모두 Difco (Difco Laboratory, Detroit, MI, USA) 제품을 사용하였다.

\section{시료 제조}

수삼을 세척한 후 인삼(RG0)은 건조기에서 건조 하였고, 홍삼 은 증숙 시간을 $2,4,6,8$ 시간으로 구분하여 증숙한 후 건조기 에서 건조하였다(Fig. 1; Table 1). 건조는 밀폐 제습식 건조기 (ACE Machinery, Seoul, Korea)를 사용하여 수분함량 $15 \%$ 미 만으로 건조하였고, 증숙은 무압식 스팀증숙기(ACE Machinery) 를 사용하여 증숙온도 90 에서 증숙하였다. 홍삼의 발효에 사용 된 균주는 구하기 쉬우며 안전성이 보장된 대표적인 균주인 Leuconostoc mesenteroides, Lactobacillus sp. MEI 823, Saccharomyces cerevisiae, Lactobacillus paracasei를 사용하여 발효하였다 (Table 2). 홍삼과 발효홍삼간의 항산화 지표와 유효 성분을 비 교하기 위해 액상발효를 하였다. 홍삼을 각각 $5 \mathrm{~g}$ 씩 칭량하여 넣고, $45 \mathrm{~mL}$ 의 멸균 증류수를 첨가하여 현탁하였다 $(10 \% \mathrm{w} / \mathrm{v})$. 시료가 포함된 용기마다 미리 혼합된 복합 효소액 $0.5 \mathrm{~mL}$ 를 첨 가하고 하룻밤 반응시켰다. 시료에 따라 정해진 균주 현탁액을 $0.5 \mathrm{~mL}$ 씩 접종하여 섭씨 35 인큐베이터에서 정치 배양하였다. 접종 시 균주의 농도는 생육에 따라 가감하여 107-108 cells $/ \mathrm{mL}$ 정도로 하였다. 샘플에 따라 간헐적으로 흔들어 주었고, 매일 같은 시간에 발효상태 $(\mathrm{pH})$ 를 확인하고 발효의 지속여부를 결정 하였다. 신손상 예방 효능을 알아보기 위해 실시한 동물실험에 필요한 시료는 고형발효를 하였다. 사각 투명 밀폐용기에 각각 라벨을 붙이고, 시료를 샘플 하나당 2개씩 각각 $50 \mathrm{~g}$ 씩(총 100 g) 칭량하여 넣었다. $250 \mathrm{~mL}$ 의 멸균 증류수를 첨가하여 현탁한 


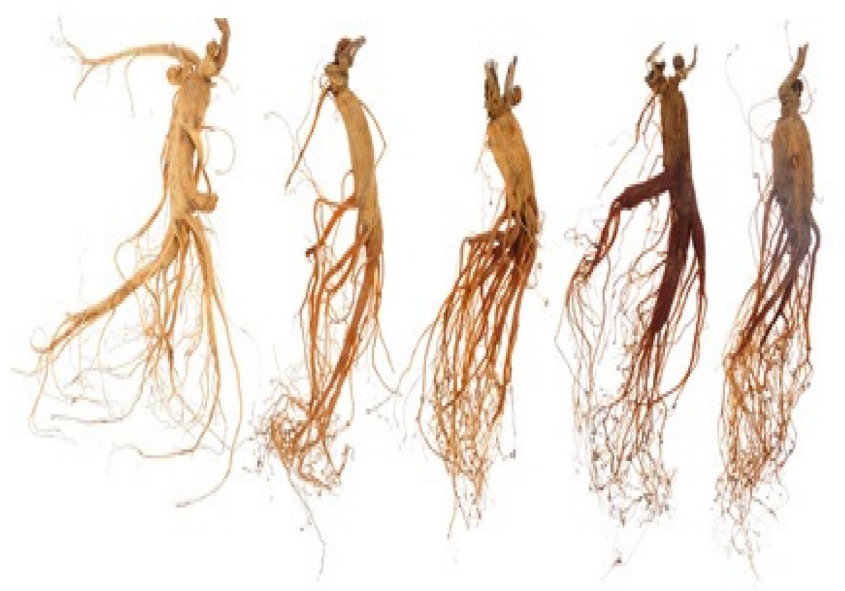

Fig. 1 Appearance of ginseng by steaming time. RG0: Dried ginseng without steaming, RG2: Steamed $2 \mathrm{~h}$ and dried Panax ginseng, RG4: Steamed $4 \mathrm{~h}$ and dried Panax ginseng, RG6: Steamed $6 \mathrm{~h}$ and dried Panax ginseng, RG8: Steamed $8 \mathrm{~h}$ and dried Panax ginseng

Table 1 Explanation of initials used in the experiments

\begin{tabular}{ll}
\hline Item & \multicolumn{1}{c}{ Explanation } \\
\hline RG0 & Dried Panax ginseng without steaming \\
RG2 & Dried Panax ginseng without steaming for 2 \\
RG4 & Dried Panax ginseng without steaming for 4 \\
RG6 & Dried Panax ginseng without steaming for 6 \\
RG8 & Dried Panax ginseng without steaming for 8 \\
\hline
\end{tabular}

다음 $(20 \% \mathrm{w} / \mathrm{v})$, 시료가 포함된 용기마다 미리 혼합된 복합 효 소액 $2 \mathrm{~mL}$ 를 첨가하고 하룻밤 반응시켰다. 그 후, 시료에 따라 정해진 균주 현탁액을 $2 \mathrm{~mL}$ 씩 접종하여 섭씨 $35^{\circ} \mathrm{C}$ 인큐베이 터에서 정치 배양하였다. 배양액은 $107-108$ cells $/ \mathrm{mL}$ 의 균주 농도에 맞추어 접종하였다. 샘플에 따라 간헐적으로 흔들어 주 었었으며, 매일 같은 시간 발효상태 $(\mathrm{pH})$ 를 확인하고 $35^{\circ} \mathrm{C}, 6$ 일 간 발효하였다. 위의 시료들을 분쇄기로 분쇄 한 다음 시료 $5 \mathrm{~g}$ 에 Distilled water $50 \mathrm{~mL}$ 를 넣고, $100{ }^{\circ} \mathrm{C}$ 에서 3시간씩 2회 반 복 추출하였다. Kimble-filtering flask에 funnel을 장착하고 여과 지(Whatman No. 2, GE healthcare, Arlington Heights, IL, USA) 를 사용하여 추출물을 여과한 뒤 여과액을 미리 항량된 용기에 넣어 $45-50^{\circ} \mathrm{C}$ 의 수온에서 rotary vacuum evaporator (JP/N-1000X, $\mathrm{EYELA}$ )를 사용하여 감압농축 후 $-30^{\circ} \mathrm{C}$ 에서 120 분, $-15^{\circ} \mathrm{C}$ 에 서 120 분, $0{ }^{\circ} \mathrm{C}$ 에서 240 분, $15^{\circ} \mathrm{C}$ 에서 120 분, $30^{\circ} \mathrm{C}$ 에서 120 분 의 조건으로 동결건조 하였다.

\section{$\mathrm{pH}$ 측정}

매일 같은 시간 발효 일수에 따른 $\mathrm{pH}$ 변화를 측정하여 발효 정도를 판단하였다(Table 4).

\section{시료 선정}

시료 선정을 위하여 홍삼을 액상 발효한 후 100 배 희석하여 항 산화 효능을 알아볼 수 있는 DPPH radical scavenging activity 와 ABTS radical scavenging activity, 그리고 각종 성분검사를 실시하였다.
Table 2 Sample abbreviations

\begin{tabular}{cl}
\hline Index & \multicolumn{1}{c}{ Species } \\
\hline F0 & Not fermented \\
F1 & Fermented with Leuconastoc mesenteroides \\
F2 & Fermented with Lactobacillus sp. MEI 823 \\
F3 & Fermented with Saccharomyces cerevisiae \\
F4 & Fermented with Lactobacillus paracasei \\
\hline
\end{tabular}

Table 3 Explanation of initials used in the experiments

\begin{tabular}{ll}
\hline Item & \multicolumn{1}{c}{ Explanation } \\
\hline RG0F0 & Not fermented dried Panax ginseng without processing* \\
RG0F1 & Dried Panax ginseng without processing* and fermented with F1 \\
RG0F2 & Dried Panax ginseng without processing* and fermented with F2 \\
RG0F3 & Dried Panax ginseng without processing* and fermented with F3 \\
RG0F4 & Dried Panax ginseng without processing* and fermented with F4 \\
RG2F0 & Not fermented Panax ginseng steamed for 2 h at $90{ }^{\circ} \mathrm{C}$ \\
RG2F1 & Panax ginseng steamed for $2 \mathrm{~h}$ at $90^{\circ} \mathrm{C}$ and fermented with F1 \\
RG2F2 & Panax ginseng steamed for $2 \mathrm{~h}$ at $90^{\circ} \mathrm{C}$ and fermented with F2 \\
RG2F3 & Panax ginseng steamed for $2 \mathrm{~h}$ at $90^{\circ} \mathrm{C}$ and fermented with F3 \\
RG2F4 & Panax ginseng steamed for $2 \mathrm{~h}$ at $90^{\circ} \mathrm{C}$ and fermented with F4 \\
RG4F0 & Not fermented Panax ginseng steamed for $4 \mathrm{~h}$ at $90{ }^{\circ} \mathrm{C}$ \\
RG4F1 & Panax ginseng steamed for $4 \mathrm{~h}$ at $90^{\circ} \mathrm{C}$ and fermented with F1 \\
RG4F2 & Panax ginseng steamed for $4 \mathrm{~h}$ at $90^{\circ} \mathrm{C}$ and fermented with F2 \\
RG4F3 & Panax ginseng steamed for $4 \mathrm{~h}$ at $90^{\circ} \mathrm{C}$ and fermented with F3 \\
RG4F4 & Panax ginseng steamed for $4 \mathrm{~h}$ at $90^{\circ} \mathrm{C}$ and fermented with F4 \\
RG6F0 & Not fermented Panax ginseng steamed for $6 \mathrm{~h}$ at $90{ }^{\circ} \mathrm{C}$ \\
RG6F1 & Panax ginseng steamed for $6 \mathrm{~h}$ at $90^{\circ} \mathrm{C}$ and fermented with F1 \\
RG6F2 & Panax ginseng steamed for $6 \mathrm{~h}$ at $90^{\circ} \mathrm{C}$ and fermented with F2 \\
RG6F3 & Panax ginseng steamed for $6 \mathrm{~h}$ at $90^{\circ} \mathrm{C}$ and fermented with F3 \\
RG6F4 & Panax ginseng steamed for $6 \mathrm{~h}$ at $90^{\circ} \mathrm{C}$ and fermented with F4 \\
RG8F0 & Not fermented Panax ginseng steamed for $8 \mathrm{~h}$ at $90{ }^{\circ} \mathrm{C}$ \\
RG8F1 & Panax ginseng steamed for $8 \mathrm{~h}$ at $90^{\circ} \mathrm{C}$ and fermented with F1 \\
RG8F2 & Panax ginseng steamed for $8 \mathrm{~h}$ at $90^{\circ} \mathrm{C}$ and fermented with F2 \\
RG8F3 & Panax ginseng steamed for $8 \mathrm{~h}$ at $90^{\circ} \mathrm{C}$ and fermented with F3 \\
RG8F4 & Panax ginseng steamed for $8 \mathrm{~h}$ at $90^{\circ} \mathrm{C}$ and fermented with F4 \\
\hline
\end{tabular}

* steaming at $90{ }^{\circ} \mathrm{C}$

Panax ginseng fermented with as below; F1: Leuconostoc mesenteroides, F2: Lactobacillus sp. MEI 823, F3: Saccharomyces cerevisiae, F4: Lactobacillus paracasei

\section{DPPH radical scavenging activity}

시료 $100 \mu \mathrm{L}$ 과 $60 \mu \mathrm{M}$ DPPH 용액(dissolved in ethanol)을 $100 \mu \mathrm{L}$ 넣고 혼합한 후, 실온에서 30 분간 반응시켰다. 이 반응 액을 사용하여 $540 \mathrm{~nm}$ 에서 흡광도를 사용하여 측정한 후, 전자 공여능은 식 (a)에 따라 계산하여 산출하였다. 식 (a) DPPH Radical scavenging activity $(\%)=\left\{\left(O D_{\text {control }}-O D_{\text {sample }}\right) / O D_{\text {control }}\right\}$ $\times 100, O D_{\text {control: }}$ 시료가 들어가지 않은 경우(대조군) 흡광도, $O D_{\text {sample: }}$ 시료가 들어간 경우 흡광도.

\section{ABTS radical scavenging activity}

$7 \mathrm{mM}$ ABTS와 $2.45 \mathrm{mM}$ Potassium persulfate를 증류수에 녹 인 다음 12 시간 동안 차광하여 보관한다. 이 반응액을 $734 \mathrm{~nm}$ 에서 ethanol을 이용하여 흡광도 $0.70 \pm 0.02$ 로 보정한다. 그 후, $\mathrm{ABTS} 95 \mu \mathrm{L}$ 에 시료 $5 \mu \mathrm{L}$ 을 첨가하여 15 분 반응 후, $734 \mathrm{~nm}$ 
에서 흡광도를 측정하였다. 흡광도는 식 (b)에 따라 계산하여 산출하였다. 식 (b) ABTS Radical scavenging activity (\%)= $\left\{\left(O D_{\text {control }}-O D_{\text {sample }}\right) / O D_{\text {control }}\right\} \times 100, O D_{\text {control }}$ : 시료가 들어가지 않은 경우(대조군) 흡광도, $O D_{\text {sample }}$ : 시료가 들어간 경우 흡광도.

\section{성분분석}

홍삼 및 액상발효홍삼 $1 \mathrm{~mL}$ 에 함유된 성분을 분석하여 함량을 표 로 나타내었다. $\mathrm{N} / \mathrm{D}$ 은 검출은 되지만 정량값이 의미가 없는 것을 의미한다. 컬럼은 $\mathrm{Xbridge}^{\mathrm{TM}} \mathrm{RP} 18,5 \mu \mathrm{m} 250 \mathrm{~mm} \times 4.6 \mathrm{~mm}$ 를 사용하였고, 용매조건은 acetonitrile과 water의 gradient 조건하에서 수해되었고, UV detector는 PDA $(203 \mathrm{~nm})$ 를 사용하였다.

\section{실험동물}

모든 실험은 대구한의대학교 동물실험 윤리위원회의 승인 (DHU2015-050)을 얻어 시행하였으며 동물관리 규정을 준수하 였다. ICR mice계의 6주령 수컷을 오리엔트(Seongnam, Gyeonggi, Korea)에서 구입하여 1주일 동안 실험실 환경에 적응시킨 후 실 험에 사용하였다. 동물 사육실의 조건은 conventional system으 로 온도 $22 \pm 2{ }^{\circ} \mathrm{C}$, 습도 $50 \pm 5 \%$, 명암주기(light: dark cycle)는 12 시간 주기로 조절하였다. 사료는 고형사료(조단백질 $22.1 \%$ 이상, 조지방 $8.0 \%$ 이하, 조섬유 $5.0 \%$ 이하, 조회분 $8.0 \%$ 이 하, 칼슘 $0.6 \%$ 이상, 인 $0.4 \%$ 이상, 항생제 무첨가, Samyang corporation, Seoul, Korea)와 물을 충분히 공급하였다.

\section{급성 신장손상 모델 및 약물 투여}

실험군은 총 4 개의 군으로 정상군과 cisplatin 투여군으로 나뉘 는데, cisplatin 투여군은 약물투여를 하지 않은 대조군, 건삼투 여군(RG0F0)과, 발효홍삼투여군(RG8F3) 으로 나누었으며 각각 9 마리씩 배정하였다. 건삼과 발효홍삼군에 1 일, 1 회 각각 200

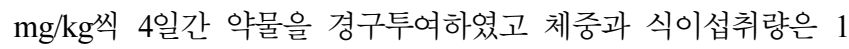
일 1회 각각 측정하였다. 4 일째, 약물투여 2시간 후 cisplatin을 식염수에 녹여 $20 \mathrm{mg} / \mathrm{kg}$ 의 농도로 복강 주사 하였다. Cisplatin 복강투여 24시간 후 개복하여 심장에서 혈액을 채취 한 후 관 류하여 액체 질소에 동결시켰고, 신장 조직을 적출하여 생리식 염수에 세척 후, 수분을 제거하자마자 액체 질소에 바로 동결 시켜 $-80^{\circ} \mathrm{C}$ deep freezer에 보관하였다.

\section{체중, 식이섭취량 및 신장무게 측정}

실험동물의 체중은 전자체중계(CAS, Gyeonggi, Korea)로 1일, 1 회, 동일 시간 동일 조건에서 측정하였고, 실험종료일 체중에 서 실험 개시 전 체중을 빼서 체중 증가량(body weight gain $(\mathrm{g})$ ) 을 산출하였다. 식이섭취량은 제공된 사료에서 하룻동안 섭취하 고 남은 사료 량을 제하여 사료의 섭취량을 측정한다. 그 후, 각 실험군마다 평균을 내어 하루 사료 섭취량을 산출하였다. Cisplatin 복강투여 24시간 후 개복하여 신장을 적출한 즉시 신 장무게를 측정하였다.

\section{혈청의 BUN 및 Creatinine 측정}

심장에서 채혈한 혈액을 $4,000 \mathrm{rpm}, 10$ 분 동안 원심 분리하여 혈청을 얻었다. 신장 기능을 측정하는 $\mathrm{BUN}$ 및 creatinine assay kit는 제작사(Asan Pharm. Co., Hwaseong, Korea)의 프로토콜 에 따라 측정하였다.

\section{ROS 및 GSH 측정}

신장조직은 $1 \mathrm{mM}$ EDTA- $50 \mathrm{mM}$ sodium phosphate buffer $(\mathrm{pH}$ 7.4)를 이용하여 분쇄하였다. ROS를 측정하기 위하여 혈청과 신 장조직에 $25 \mathrm{mM} \mathrm{DCFH-DA}$ 를 혼합한 후, 형광 광도계를 이용 하여 0 분부터 매 10 분씩 emission wavelength of $530 \mathrm{~nm}$ 와 excitation wavelength of $486 \mathrm{~nm}$ 에서 30 분간 측정한 산출 값을 계산하였다. $\mathrm{GSH}$ 를 측정하기 위하여 혈청과 신장조직에 $0.1 \mathrm{M}$ Sodium phosphate buffer ( $\mathrm{pH}$ 8.0)와 OPA solution을 혼합한 후, 실온 15 분 인큐베이션 후 형광 광도계를 이용하여 emission wavelength of $420 \mathrm{~nm}$ 와 excitation wavelength of $350 \mathrm{~nm}$ 에서 측정한 산출 값을 계산하였다.

\section{Western blot analysis}

신장 조직의 세포질단백질을 얻기 위해 $100 \mathrm{mM}$ Tris- $\mathrm{HCl}(\mathrm{pH}$ 7.4), $5 \mathrm{mM}$ Tris- $\mathrm{HCl}(\mathrm{pH} 7.5), 2 \mathrm{mM} \mathrm{MgCl}, 15 \mathrm{mM} \mathrm{CaCl}_{2}$, and $1.5 \mathrm{M}$ sucrose, $0.1 \mathrm{M} \mathrm{DTT}$, and protease inhibitor cocktail 을 첨가한 buffer $\mathrm{A}$ 를 넣고 tissue grinder (Bio Spec Product, Bartlesville, OK, USA)로 분쇄한 후 $10 \% \mathrm{NP}-40$ 용액을 첨가 하였다. 아이스 위에서 20 분간 정치시킨 후 $12,000 \mathrm{rpm}$ 으로 2 분간 원심분리 하여 세포질 단백질을 포함하고 있는 상층액을 분리하였다. 핵단백질을 얻기 위해 $10 \% \mathrm{NP}-40$ 가 더해진 buffer $\mathrm{A}$ 에 두 번 헹구고 $100 \mu \mathrm{L}$ 의 buffer C $(50 \mathrm{mM}$ HEPES, $50 \mathrm{mM}$ $\mathrm{KCl}, 0.3 \mathrm{mM} \mathrm{NaCl}, 0.1 \mathrm{mM}$ EDTA, $1 \mathrm{mM}$ DTT, $0.1 \mathrm{mM}$ $\mathrm{PMSF}$ and $10 \%$ glycerol)를 첨가해 재부유 시킨 뒤 10 분마다 vortex를 3 번 하였다. $4{ }^{\circ} \mathrm{C}$ 에서 $12,000 \mathrm{rpm}$ 으로 10 분간 원심 분 리한 후 핵단백질을 포함하고 있는 상층액을 얻어 $-80{ }^{\circ} \mathrm{C}$ 에서 각각 냉동 보관하였다.

신장조직의 세포질 단백질인 SOD-1, catalase, GPx, iNOS, $\mathrm{COX}-2, \mathrm{TNF}-\alpha$, IL-6, HO-1, $\beta$-actin 및 핵단백질인 Histone, $\mathrm{NF}-\kappa \mathrm{B}$ p $65, \mathrm{Nrf}-2$ 의 발현을 측정하기 위해 $10 \mu \mathrm{g}$ 의 단백질을 8-15\% SDS-polyacrylamide gel을 이용하여 전기영동 후, acrylamide gel을 nitrocellulose membrane으로 이동시켰다. $5 \%$ skim milk를 함유한 TBS-T $(0.5 \%$ Tween 20 in TBS $)$ 에 담 그고 1 시간 동안 blocking 처리한 후 TBS-T로 5분마다 5회 세 척하였다. 준비된 membrane에 각각의 1차 antibody를 처리하여 $4{ }^{\circ} \mathrm{C}$ 에서 overnight시킨 다음 TBS-T로 10 분마다 5 회 세척하고, 각각 처리된 1 차 항체에 사용되는 2차 항체(TBS-T로 1:5000 로 희석해서 사용)를 사용하여 상온에서 1 시간 30 분간 반응시 킨 후, TBS-T로 10 분마다 5회 세척하였다. 그리고 ECL 용액 을 $\mathrm{GE}$ Healthcare (Arlington Heights, IL, USA)에 노출시킨 후, Sensi-Q2000 Chemidoc (Lugen Sci Co., Ltd., Seoul, Korea) 에 감광시켜 단백질 발현을 확인한 후, 해당 band를 ATTO Densitograph Software (ATTO Corporation, Tokyo, Japan)프로 그램을 사용하여 정량하였다.

\section{조직학적 분석}

신장 조직을 적출한 다음 조직을 절단하고, $10 \%$ 중성포르말린 에 18 시간 이상 고정시킨 다음, 탈수를 거쳐 파라핀 포매 후 $4 \mu \mathrm{m}$ 의 절편을 제작하였다. 이후 Hematoxylin-eosin (H \& E) 염색을 실시하고, 광학 현미경을 이용하여 관찰하였다. 
Table $4 \mathrm{pH}$ of ginseng and fermented red ginseng

\begin{tabular}{|c|c|c|c|c|c|}
\hline \multirow{2}{*}{\multicolumn{2}{|c|}{ Items }} & \multicolumn{4}{|c|}{ Fermented period (days) } \\
\hline & & 0 & 1 & 4 & 7 \\
\hline \multirow{4}{*}{ RG0 } & F1 & \multirow{4}{*}{5.5} & 4.4 & 3.86 & 3.92 \\
\hline & $\mathrm{F} 2$ & & 4.1 & 3.92 & 3.81 \\
\hline & F3 & & 4.4 & 4.26 & 4.26 \\
\hline & $\mathrm{F} 4$ & & 3.47 & 3.33 & 3.25 \\
\hline \multirow{4}{*}{ RG2 } & F1 & \multirow{4}{*}{5.41} & 3.36 & 3.18 & 3.18 \\
\hline & $\mathrm{F} 2$ & & 3.8 & 3.8 & 3.9 \\
\hline & F3 & & 4.68 & 4.45 & 4.35 \\
\hline & $\mathrm{F} 4$ & & 3.33 & 3.2 & 3.25 \\
\hline \multirow{4}{*}{ RG4 } & $\mathrm{F} 1$ & \multirow{4}{*}{4.64} & 3.6 & 3.31 & 3.19 \\
\hline & $\mathrm{F} 2$ & & 3.34 & 3.1 & 3.08 \\
\hline & F3 & & 4.4 & 4.29 & 4.19 \\
\hline & F4 & & 3.91 & 3.46 & 3.44 \\
\hline \multirow{4}{*}{ RG6 } & F1 & \multirow{4}{*}{4.35} & 3.31 & 3.53 & 3.5 \\
\hline & $\mathrm{F} 2$ & & 4.29 & 3.63 & 3.6 \\
\hline & F3 & & 5.01 & 4.13 & 4.08 \\
\hline & F4 & & 3.96 & 3.21 & 3.25 \\
\hline \multirow{4}{*}{ RG8 } & F1 & \multirow{4}{*}{4.15} & 3.91 & 3.48 & 3.44 \\
\hline & $\mathrm{F} 2$ & & 3.4 & 3.7 & 3.08 \\
\hline & F3 & & 4.26 & 4.12 & 4.1 \\
\hline & F4 & & 3.33 & 3.21 & 3.15 \\
\hline
\end{tabular}

RG0: Dried ginseng, RG2: steamed $2 \mathrm{~h}$ and dried ginseng, RG4: steamed $4 \mathrm{~h}$ and dried ginseng, RG6: steamed $6 \mathrm{~h}$ and dried ginseng, RG8: steamed $8 \mathrm{~h}$ and dried ginseng, F1: Leuconostoc mesenteroides, F2: Lactobacillus sp. MEI 823, F3: Saccharomyces cerevisiae, F4: Lactobacillus paracasei

\section{통계처리}

실험결과는 평균과 표준편차 $(m e a n \pm \mathrm{SD})$ 로 표기하였으며, SPSS 22.0 for Windows program을 사용하여 one-way analysis of variance (ANOVA) test를 실시한 다음 least-significant differences test로 사후 검증을 실시하여 군 간의 유의성을 측정하였다. 유 의수준 $p$-value $<0.05$ 에서 검정하였다.

\section{결 과}

\section{발효에 따른 $\mathbf{p H}$ 변화}

건삼과 홍삼의 발효 일수에 따른 $\mathrm{pH}$ 변화를 측정하여 발효 정 도를 판단하였다. 본 측정 결과는 발효를 진행 할수록 $\mathrm{pH}$ 가 낮 아지기 때문에 $\mathrm{pH}$ 의 정도는 발효 정도를 나타낸다. 발효하지 않은 건삼 및 홍삼을 보면 건삼은 5.5이고 RG2부터 RG8로 갈 수록 $\mathrm{pH}$ 가 낮은 것을 알 수 있었고 발효 기간이 길어질수록 $\mathrm{pH}$ 가 낮아지는 경향을 보였다(Table 4).

\section{DPPH radical scavenging activity}

$\mathrm{RG} 0 \mathrm{~F} 0$ 는 $15.20 \pm 0.61 \%$ 의 항산화 활성을 보인데 비해, RG8F3 는 $36.41 \pm 0.43 \%$ 의 높은 항산화 활성을 나타내었다. 6시간 증 숙 한 후, 1 번 균주로 발효한 홍삼이 $33.03 \pm 0.84 \%$ 로 그 다음 으로 높은 활성을 보였다(Table 5).

\section{ABTS radical scavenging activity}

$\mathrm{ABTS}$ 라디칼 소거능은 발효를 한 시료보다 발효하지 않은 시 료들이 높은 효과를 보였다. $\mathrm{RG} 0 \mathrm{~F} 0$ 는 $25.74 \pm 0.28 \%$ 의 소거능 을 보였고, $\mathrm{RG} 6 \mathrm{~F} 0$ 는 $27.30 \pm 1.12 \%$ 로 가장 높은 효과를 보였으 며, RG8F0가 $27.21 \pm 0.59 \%$ 로서 이와 유사한 효과를 보였다. 홍 삼 중에서는 RG8F3가 $20.91 \pm 0.63 \%$ 로 가장 높은 효과를 보였 다(Table 6).

\section{성분분석}

$\mathrm{RG} 0 \mathrm{~F} 0$ 는 총 사포닌 함량이 1.867 을 보인 반면, $\mathrm{RG} 0 \mathrm{~F} 4$ 의 경우,

Table 5 DPPH radical scavenging activity

\begin{tabular}{ccccc}
\hline & F0 & F1 & F2 & F3 \\
\hline RG0 & $15.20 \% \pm 0.61$ & $18.03 \% \pm 0.33 * * *$ & $05.91 \% \pm 1.07 * *$ & $11.21 \% \pm 0.35$ \\
RG2 & $19.07 \% \pm 1.23$ & $21.1 \% \pm 0.79 *$ & $23.47 \% \pm 1.09$ & $19.39 \% \pm 0.91$ \\
RG4 & $20.28 \% \pm 1.03 * * *$ & $25.84 \% \pm 1.14 * *$ & $24.19 \% \pm 0.71 * * *$ & $09.58 \% \pm 0.65 * * *$ \\
RG6 & $25.60 \% \pm 0.38 * * *$ & $33.03 \% \pm 0.84 * * *$ & $25.00 \% \pm 1.51 * * *$ & $28.90 \% \pm 1.15 * * *$ \\
RG8 & $23.48 \% \pm 1.39$ & $16.10 \% \pm 0.69$ & $16.72 \% \pm 1.57 * * *$ & $36.41 \% \pm 0.43$ \\
\hline
\end{tabular}

RG0: Dried ginseng, RG2: steamed $2 \mathrm{~h}$ and dried ginseng, RG4: steamed $4 \mathrm{~h}$ and dried ginseng, RG6: steamed 6 h and dried ginseng, RG8: steamed 8 $\mathrm{h}$ and dried ginseng, F1: Leuconostoc mesenteroides, F2: Lactobacillus sp. MEI 823, F3: Saccharomyces cerevisiae, F4: Lactobacillus paracasei Significance was compared to RG0F0 $(* p<0.05, * * p<0.01, * * * p<0.001)$

Table 6 ABTS radical scavenging activity.

\begin{tabular}{ccccc}
\hline & F0 & F1 & F2 & F3 \\
\hline RG0 & $25.74 \% \pm 0.28$ & $15.18 \% \pm 0.55$ & $13.92 \% \pm 0.55$ & $14.09 \% \pm 0.21$ \\
RG2 & $22.05 \% \pm 0.06$ & $15.22 \% \pm 0.10$ & $16.00 \% \pm 0.70$ & $17.58 \% \pm 0.31$ \\
RG4 & $26.09 \% \pm 0.67$ & $12.80 \% \pm 0.81$ & $13.04 \% \pm 0.37$ & $14.23 \% \pm 0.08$ \\
RG6 & $27.30 \% \pm 1.12 *$ & $18.72 \% \pm 0.74$ & $17.26 \% \pm 0.79$ & $17.39 \% \pm 0.76$ \\
RG8 & $27.21 \% \pm 0.59$ & $14.60 \% \pm 0.23$ & $17.05 \% \pm 0.17 * *$ & $20.91 \% \pm 0.63$ \\
\hline
\end{tabular}

RG0: Dried ginseng, RG2: steamed $2 \mathrm{~h}$ and dried ginseng, RG4: steamed $4 \mathrm{~h}$ and dried ginseng, RG6: steamed $6 \mathrm{~h}$ and dried ginseng, RG8: steamed 8 hs and dried ginseng, F1: Leuconostoc mesenteroides, F2: Lactobacillus sp. MEI 823, F3: Saccharomyces cerevisiae, F4: Lactobacillus paracasei Significance was compared to RG0F0 $\left({ }^{*} p<0.01,{ }^{* *} p<0.001\right)$ 
Table 7 Ginsenosides components of ginseng by steaming and fermentation with different strains

\begin{tabular}{|c|c|c|c|c|c|}
\hline & RG0F0 & RG0F1 & RG0F2 & RG0F3 & RG0F4 \\
\hline Standard & 26 & 31 & 32 & 33 & 34 \\
\hline Rg1 & 0.47 & 0.656 & 2.825 & 3.489 & 2.553 \\
\hline $\mathrm{Re}$ & 0.259 & 0.241 & 1.032 & 1.253 & 0.903 \\
\hline $\mathrm{Rf}$ & 0.181 & 0.134 & 0.664 & 0.754 & 0.857 \\
\hline Rb1 & 0.662 & N/D & N/D & 0.076 & N/D \\
\hline $\operatorname{Rg} 2(s)$ & 0.028 & 0.03 & 0.157 & 0.151 & 0.394 \\
\hline $\mathrm{Rc}$ & 0.269 & 0.069 & 0.335 & 0.767 & 0.84 \\
\hline $\operatorname{Rg} 2(r)$ & 0.035 & N/D & 0.057 & 0.04 & 0.144 \\
\hline $\mathrm{Rb} 2$ & 0.174 & 0.189 & 0.596 & 0.811 & 0.887 \\
\hline $\mathrm{Rb} 3$ & 0.036 & 0.039 & 0.09 & 0.14 & 0.159 \\
\hline $\mathrm{F} 1$ & N/D & 0.018 & 0.068 & 0.074 & 0.039 \\
\hline $\mathrm{Rd}$ & 0.055 & 0.394 & 1.163 & 1.835 & 1.677 \\
\hline Rg6 & N/D & N/D & 0.036 & N/D & 0.221 \\
\hline $\mathrm{F} 4+\mathrm{Rk} 3$ & N/D & 0.005 & 0.029 & 0.025 & 0.152 \\
\hline F2 & N/D & 0.029 & 0.113 & 0.074 & 0.118 \\
\hline Rh4 & $\mathrm{N} / \mathrm{D}$ & 0.012 & 0.051 & 0.045 & 0.25 \\
\hline $\operatorname{Rg} 3(s)$ & 0.018 & 0.011 & 0.044 & 0.05 & 0.127 \\
\hline $\operatorname{Rg} 3(r)$ & N/D & 0.01 & 0.063 & 0.007 & 0.077 \\
\hline CK & N/D & 0.001 & 0.006 & 0.022 & 0.003 \\
\hline $\mathrm{Rk} 1$ & 0.012 & N/D & 0.034 & 0.014 & 0.11 \\
\hline Rg5 & N/D & 0.013 & 0.073 & 0.094 & 0.457 \\
\hline Total & 1.867 & 1.853 & 7.435 & 9.72 & 9.969 \\
\hline
\end{tabular}

RG0F0: Dried ginseng, RG0F1: dried and fermented with Leuconostoc mesenteroides, RG0F2: dried and fermented with Lactobacillus sp. MEI 823, RG0F3: dried and fermented with Saccharomyces cerevisiae, RG0F4: dried and fermented with Lactobacillus paracasei

9.969의 함량을 보였고, RG0F3이 9.72로 두 번째로 높은 함량 을 보였다.

그러나 증숙 후 발효한 홍삼은, 발효하지 않은 홍삼에 비하 여 성분 함량이 낮은 것을 확인 할 수 있었다(Table 7).

\section{최종 시료 선정}

수삼을 건조만 한 건삼, 수삼을 $2,4,6,8$ 시간 증숙한 홍삼, 그 리고 건삼과 4 가지 홍삼을 4 가지 균주로 발효한 시료의 성분 분석과 in vitro 항산화 실험을 한 결과, $\mathrm{RG} 0 \mathrm{~F} 0$ 와 $\mathrm{RG8F}$ 간 의 효능 평가가 가능할 것으로 사료되어 최종 시료로 선정하였다.

Cisplatin에 의한 급성 신장 손상 동물 모델의 체중, 식이섭취 량 및 신장무게의 변화

투여 군들의 체중 증가만 유의성 있는 증가를 보였고 식이섭취 량에는 변화를 보이지 않았다. 신장무게는 대조군에서 정상 군 과 비교하였을 경우 약간 증가하는 경향을 보였다(Table 8).

\section{ROS 및 GSH 변화}

4일간 약물투여 하고 cisplatin 복강투여 24시간 후 개복하여 심 장에서 혈액을 채취 한 후 관류하여 신장 조직을 적출하였다. 이후 분쇄한 신장 조직에서 산화적 스트레스 바이오 마커인 $\mathrm{ROS}, \mathrm{GSH}$ 를 측정한 결과 $\mathrm{ROS}$ 의 값은 정상군 $(3186.9 \pm 106.2$

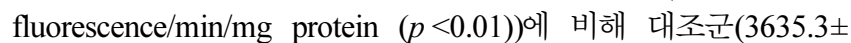
61.4 fluorescence $/ \mathrm{min} / \mathrm{mg}$ protein)에서 수치가 증가하였다.
Table 7 Continued

\begin{tabular}{|c|c|c|c|c|c|}
\hline & $\mathrm{RG} 2 \mathrm{~F} 0$ & RG2F1 & RG2F2 & RG2F3 & RG2F4 \\
\hline Standard & 27 & 35 & 36 & 37 & 38 \\
\hline Rg1 & 0.646 & 0.31 & 0.55 & 0.814 & 0.406 \\
\hline $\mathrm{Re}$ & 0.324 & 0.113 & 0.188 & 0.301 & 0.146 \\
\hline $\mathrm{Rf}$ & 0.189 & 0.107 & 0.126 & 0.16 & 0.12 \\
\hline $\mathrm{Rb} 1$ & 1.249 & N/D & N/D & N/D & N/D \\
\hline $\operatorname{Rg} 2(s)$ & 0.034 & 0.067 & 0.051 & 0.036 & 0.067 \\
\hline $\mathrm{Rc}$ & 0.702 & 0.072 & 0.083 & 0.264 & 0.081 \\
\hline $\operatorname{Rg} 2(r)$ & 0.013 & 0.028 & 0.015 & 0.008 & 0.024 \\
\hline Rb2 & 0.394 & 0.076 & 0.091 & 0.288 & 0.081 \\
\hline $\mathrm{Rb} 3$ & 0.084 & 0.011 & 0.016 & N/D & 0.015 \\
\hline $\mathrm{F} 1$ & 0.035 & N/D & N/D & 0.006 & N/D \\
\hline $\mathrm{Rd}$ & 0.087 & 0.078 & 0.071 & 0.363 & 0.062 \\
\hline $\operatorname{Rg} 6$ & N/D & 0.009 & 0.01 & 0.007 & 0.013 \\
\hline $\mathrm{F} 4+\mathrm{Rk} 3$ & 0.007 & 0.017 & 0.009 & 0.006 & 0.013 \\
\hline F2 & 0.014 & N/D & N/D & N/D & $\mathrm{N} / \mathrm{D}$ \\
\hline Rh4 & N/D & 0.028 & 0.016 & 0.01 & 0.028 \\
\hline $\operatorname{Rg} 3(\mathrm{~s})$ & 0.021 & 0.012 & 0.012 & N/D & 0.006 \\
\hline $\operatorname{Rg} 3(r)$ & 0.01 & 0.009 & 0.005 & N/D & 0.005 \\
\hline CK & N/D & N/D & N/D & N/D & N/D \\
\hline Rk1 & 0.021 & 0.024 & N/D & N/D & N/D \\
\hline $\operatorname{Rg} 5$ & 0.034 & 0.054 & 0.011 & 0.014 & 0.021 \\
\hline Total & 3.862 & 1.015 & 1.254 & 2.284 & 1.087 \\
\hline
\end{tabular}

RG2F0: steamed $2 \mathrm{~h}$ and dried ginseng, RG2F1: steamed $2 \mathrm{~h}$ and dried and fermented with Leuconostoc mesenteroides red ginseng, RG2F2: steamed $2 \mathrm{~h}$ and dried and fermented with Lactobacillus sp. MEI 823 red ginseng, RG2F3: steamed $2 \mathrm{~h}$ and dried and fermented with Saccharomyces cerevisiae red ginseng, RG2F4: steamed $2 \mathrm{~h}$ and dried and fermented with Lactobacillus paracasei red ginseng

RG0F0 투여군(3392.2 \pm 124.1 fluorescence/min/mg protein)에서 는 대조군에 비해 적은 증가 경향을 나타내었고, RG8F3 투여 군(3180.2 \pm 121.8 fluorescence $/ \mathrm{min} / \mathrm{mg}$ protein $(p<0.01))$ 에서는 대조군에 비해 유의성 있게 적은 증가를 보였다. 조직에서의 $\mathrm{GSH}$ 의 값 역시 대조군 $(421 \pm 9 \mu \mathrm{M} / \mathrm{mg}$ protein)에 비해 $\mathrm{RG} 0 \mathrm{~F} 0$ 투여군 $(451.2 \pm 8.7 \mu \mathrm{M} / \mathrm{mg}$ protein $(p<0.05))$ 과 $\mathrm{RG8F} 3$ 투여군 $(475.2 \pm 8.6 \mu \mathrm{M} / \mathrm{mg}$ protein $(p<0.001))$ 에서는 유의성 있게 증가 하였다(Fig. 2).

\section{혈청의 BUN 및 creatinine의 변화}

분리된 혈청을 이용하여 $\mathrm{BUN}$, creatinine을 측정한 결과 대조 군 $(26.12 \pm 1.59 \mathrm{mg} / \mathrm{dL})$ 은 정상군 $(22.30 \pm 0.61 \mathrm{mg} / \mathrm{dL} \quad(p<0.01))$ 에 비해 수치가 증가하였고, RG0F0 투여군 $(21.51 \pm 1.56 \mathrm{mg} / \mathrm{dL}$ $(p<0.001))$ 과 $\mathrm{RG} 8 \mathrm{~F} 3$ 투여군 $(22.24 \pm 1.56 \mathrm{mg} / \mathrm{dL} \quad(p<0.01))$ 에서 는 대조군에 비해 유의성 있게 적은 증가를 보였다. Creatinine은 대조군 $(1.93 \pm 0.01 \mathrm{mg} / \mathrm{dL})$ 은 정상군 $(1.85 \pm 0.01 \mathrm{mg} / \mathrm{dL}(p<0.001))$ 에 비해 수치가 증가하였고, RG0F0 투여군 $(1.85 \pm 0.01 \mathrm{mg} / \mathrm{dL}$ $(p<0.001))$ 과 $\mathrm{RG} 8 \mathrm{~F} 3$ 투여군 $(1.85 \pm 0.01 \mathrm{mg} / \mathrm{dL} \quad(p<0.001))$ 에서 는 대조군에 비해 유의성 있게 적은 증가를 보였다(Fig. 3).

\section{신장조직의 항산화 단백질 발현}

실험 종료 후 신장 조직을 적출- 분쇄 후 western blot을 실시 하여 항산화 효소인 SOD-1, catalase, GPx, Nrf-2와 HO-1를 
Table 7 Continued

\begin{tabular}{|c|c|c|c|c|c|}
\hline & RG4F0 & RG4F1 & RG4F2 & RG4F3 & RG4F4 \\
\hline Standard & 28 & 39 & 40 & 41 & 42 \\
\hline Rg1 & 0.559 & 0.403 & 0.215 & 0.449 & 0.3 \\
\hline $\operatorname{Re}$ & 0.277 & 0.152 & 0.081 & 0.169 & 0.114 \\
\hline $\mathrm{Rf}$ & 0.168 & 0.108 & 0.076 & 0.096 & 0.085 \\
\hline $\mathrm{Rb} 1$ & 1.33 & N/D & N/D & N/D & N/D \\
\hline $\operatorname{Rg} 2(\mathrm{~s})$ & 0.288 & 0.047 & 0.053 & 0.029 & 0.051 \\
\hline $\mathrm{Rc}$ & 0.833 & 0.082 & 0.062 & 0.08 & 0.066 \\
\hline $\operatorname{Rg} 2(r)$ & 0.032 & 0.024 & 0.022 & 0.003 & 0.018 \\
\hline $\mathrm{Rb} 2$ & 0.469 & 0.096 & 0.05 & 0.097 & 0.062 \\
\hline $\mathrm{Rb} 3$ & 0.084 & 0.014 & 0.07 & N/D & N/D \\
\hline $\mathrm{F} 1$ & 0.045 & N/D & N/D & N/D & N/D \\
\hline $\mathrm{Rd}$ & 0.102 & 0.055 & 0.055 & 0.082 & 0.058 \\
\hline Rg6 & N/D & N/D & 0.01 & N/D & 0.022 \\
\hline $\mathrm{F} 4+\mathrm{Rk} 3$ & 0.01 & 0.007 & 0.014 & 0.007 & 0.011 \\
\hline F2 & N/D & N/D & $\mathrm{N} / \mathrm{D}$ & $\mathrm{N} / \mathrm{D}$ & N/D \\
\hline $\mathrm{Rh} 4$ & 0.039 & 0.016 & 0.022 & 0.012 & 0.021 \\
\hline Rg3(s) & 0.063 & N/D & N/D & 0.012 & 0.018 \\
\hline $\operatorname{Rg} 3(r)$ & 0.018 & N/D & N/D & N/D & 0.005 \\
\hline CK & N/D & N/D & N/D & N/D & N/D \\
\hline Rk1 & 0.051 & N/D & N/D & N/D & N/D \\
\hline $\operatorname{Rg} 5$ & 0.061 & 0.012 & 0.028 & 0.031 & 0.038 \\
\hline Total & 4.435 & 1.01 & 0.76 & 1.066 & 0.914 \\
\hline
\end{tabular}

RG4F0: steamed $4 \mathrm{~h}$ and dried ginseng, RG4F1: steamed $4 \mathrm{~h}$ and dried and fermented with Leuconostoc mesenteroides red ginseng, RG4F2: steamed $4 \mathrm{~h}$ and dried and fermented with Lactobacillus sp. MEI 823 red ginseng, RG4F3: steamed $4 \mathrm{~h}$ and dried and fermented with Saccharomyces cerevisiae red ginseng, RG4F4: steamed $4 \mathrm{~h}$ and dried and fermented with Lactobacillus paracasei red ginseng

측정하였다. 그 결과 SOD-1, catalase와 Nrf-2의 발현은 대조군 에 비해 $\mathrm{RG} 0 \mathrm{~F} 0$ 와 RG8F3 투여군에서 증가하는 경향을 보였고, 대조군에 비해 $\mathrm{RG} 0 \mathrm{~F} 0$ 와 RG8F3 투여군에서는 $\mathrm{HO}-1 \quad(p<0.05)$ 과 $\operatorname{GPx}(p<0.01)$ 의 발현 역시 유의성 있게 증가하였다(Figs. $4 ; 5)$.

\section{신장조직의 염증성 사이토카인 및 매개인자 발현}

염증의 매개인자인 NF-kB p65를 측정한 결과, 대조군은 정상 군에 비해 증가 $(p<0.05)$ 하였고 $\mathrm{RG} 8 \mathrm{~F} 3$ 투여군에서는 정상군에 가까운 발현을 보였다 $(p<0.01)$ (Fig. 6). 또한 대조군의 신장조 직에서 $\mathrm{COX}-2, \mathrm{iNOS}, \mathrm{TNF}-\alpha$ 와 IL-6의 발현을 확인한 결과, 대조군과 비교하였을 때 $\mathrm{RG} 0 \mathrm{~F} 0$ 와 $\mathrm{RG} 8 \mathrm{~F} 3$ 투여군에서 $\mathrm{COX}-2$, $\mathrm{iNOS}$ 와 $\mathrm{TNF}-\alpha$ 가 유의성 있게 정상군에 가까운 발현을 보였다. 그러나 IL-6의 경우, 대조군에서는 정상군 $(p<0.01)$ 에 비해 유의 성 있게 증가하였으나 RG0F0 투여군은 대조군에 비해 유의성 있게 적은 발현을 보였다(Fig. 7).

\section{조직학적 분석 결과}

적출한 신장 조직을 $\mathrm{H \& E}$ 염색 하였다. 대조군은 사구체와 세 뇨관들에 심한 변성이 나타났지만 백삼과 발효홍삼 투여군에서 대조군과 비교하였을 때 병리조직학적 변화가 현저히 감소하였 다. 특히 RG8F3 투여군에서는 정상군과 유사한 모습을 보였다 (Fig. 8).
Table 7 Continued

\begin{tabular}{|c|c|c|c|c|c|}
\hline & RG6F0 & RG6F1 & RG6F2 & RG6F3 & RG6F4 \\
\hline Standard & 29 & 43 & 44 & 45 & 46 \\
\hline Rg1 & 0.47 & N/D & 0.062 & 0.126 & N/D \\
\hline $\mathrm{Re}$ & 0.251 & N/D & 0.022 & 0.056 & N/D \\
\hline $\mathrm{Rf}$ & 0.191 & N/D & 0.015 & 0.037 & N/D \\
\hline $\mathrm{Rb} 1$ & 1.357 & N/D & N/D & N/D & N/D \\
\hline $\operatorname{Rg} 2(s)$ & 0.049 & N/D & 0.005 & 0.011 & N/D \\
\hline $\mathrm{Rc}$ & 0.854 & N/D & 0.007 & 0.017 & N/D \\
\hline $\operatorname{Rg} 2(r)$ & 0.018 & N/D & N/D & N/D & N/D \\
\hline $\mathrm{Rb} 2$ & 0.444 & N/D & 0.011 & 0.028 & N/D \\
\hline $\mathrm{Rb} 3$ & 0.089 & N/D & N/D & N/D & N/D \\
\hline $\mathrm{F} 1$ & 0.048 & N/D & N/D & N/D & N/D \\
\hline $\mathrm{Rd}$ & 0.132 & N/D & N/D & 0.027 & N/D \\
\hline Rg6 & 0.053 & N/D & N/D & N/D & N/D \\
\hline $\mathrm{F} 4+\mathrm{Rk} 3$ & 0.044 & N/D & 0.001 & 0.003 & N/D \\
\hline $\mathrm{F} 2$ & N/D & N/D & N/D & N/D & N/D \\
\hline Rh4 & 0.041 & N/D & N/D & 0.009 & N/D \\
\hline $\operatorname{Rg} 3(s)$ & 0.07 & N/D & N/D & 0.001 & N/D \\
\hline $\operatorname{Rg} 3(r)$ & 0.026 & N/D & N/D & 0.002 & N/D \\
\hline CK & N/D & N/D & N/D & N/D & N/D \\
\hline Rk1 & 0.099 & N/D & N/D & 0.012 & N/D \\
\hline $\operatorname{Rg} 5$ & 0.269 & N/D & 0.006 & N/D & N/D \\
\hline Total & 4.506 & 0 & 0.128 & 0.328 & 0 \\
\hline
\end{tabular}

RG6F0: steamed $6 \mathrm{~h}$ and dried ginseng, RG6F1: steamed $6 \mathrm{~h}$ and dried and fermented with Leuconostoc mesenteroides red ginseng, RG6F2: steamed $6 \mathrm{~h}$ and dried and fermented with Lactobacillus sp. MEI 823 red ginseng, RG6F3: steamed $6 \mathrm{~h}$ and dried and fermented with Saccharomyces cerevisiae red ginseng, RG6F4: steamed $6 \mathrm{~h}$ and dried and fermented with Lactobacillus paracasei red ginseng

\section{고 찰}

홍삼(紅茲)은 수삼을 증기나 그 밖의 방법으로 쪄서 익혀 말린 것으로서 담적갈색 - 담황갈색 - 다갈색 또는 농다갈색의 색상 을 띠는 것을 말한다. 인삼의 주된 약리 성분은 saponin으로, 배 당체 화합물의 일종이며 triterpenoid계 사포닌과 steroid계 사포 닌으로 분류된다. 증숙 과정에서 수삼에 없는 인체에 유용한 생 리활성물질인 ginsenoside들이 생성되며, 보관도 용이하게 된다. 고려인삼에서 관찰 가능한 사포닌은 triterpenoid dammarane골 격에 당이 결합되어 있는 배당체 형태로서 당이 분해해야만 더 많은 생리활성을 나타낸다. 인삼 사포닌은 ginsenoside라 명명 되었으며, 이는 인삼의 glycoside 라는 뜻이다. 현재 약 38 종의 ginsenoside가 밝혀져 있으며, 분석기술의 발전으로 계속 새로운 구조가 밝혀지고 있다. 백삼에는 protopanaxadiol 14종, protopanaxtriol 7종, Olein 1종, 총22종의 ginsenoside 있으며, 홍삼 에는 protopanaxadiol 20종, protopanaxtriol 11종, Olein 1종 등 총 32 종이 존재하는 것으로 알려져 있다. 백삼에 없는 홍삼 의 10 가지 ginsenoside는 홍삼을 제조하는 과정에서 생성되는 홍삼 특유의 사포닌이다(Park 등, 2003).

수삼을 증숙하게 되면 가수 분해에 의해 수삼에 없는 ginsenoside 가 생성된다. ginsenoside Rs1, Rs2, Gr3 (20S), Rg3 (20R), $\mathrm{Rh} 2, \mathrm{Rs} 3, \mathrm{Rs} 4, \mathrm{Rg} 5, \mathrm{~F} 4, \mathrm{R} 4, \mathrm{Rg} 6$ 등이 있으며 특히 Rb1이 가수분해 되면서 생성되는 $\mathrm{Rg} 3$ 는 홍삼에서만 검출되는 화합물 
Table 7 Continued

\begin{tabular}{cccccc}
\hline & RG8F0 & RG8F1 & RG8F2 & RG8F3 & RG8F4 \\
\hline Standard & 30 & 47 & 48 & 49 & 50 \\
Rg1 & 0.54 & 0.365 & 0.295 & 0.655 & 0.269 \\
Re & 0.267 & 0.182 & 0.106 & 0.289 & 0.104 \\
Rf & 0.182 & 0.123 & 0.099 & 0.169 & 0.103 \\
Rb1 & 1.493 & N/D & N/D & N/D & N/D \\
Rg2(s) & 0.053 & 0.064 & 0.067 & 0.068 & 0.068 \\
Rc & 0.964 & 0.156 & 0.082 & 0.207 & 0.079 \\
Rg2(r) & 0.025 & 0.023 & 0.029 & 0.024 & 0.029 \\
Rb2 & 0.5 & 0.105 & 0.092 & 0.204 & 0.083 \\
Rb3 & 0.101 & 0.022 & 0.011 & 0.033 & 0.017 \\
F1 & 0.049 & N/D & 0.008 & N/D & N/D \\
Rd & 0.14 & 0.113 & 0.074 & 0.201 & 0.074 \\
Rg6 & 0.038 & N/D & 0.034 & 0.019 & 0.022 \\
F4+Rk3 & 0.04 & 0.024 & 0.018 & 0.025 & 0.016 \\
F2 & N/D & N/D & N/D & N/D & N/D \\
Rh4 & 0.055 & 0.043 & 0.03 & 0.041 & 0.03 \\
Rg3(s) & 0.074 & 0.023 & 0.014 & 0.022 & 0.021 \\
Rg3(r) & 0.022 & 0.019 & 0.01 & 0.022 & 0.009 \\
CK & N/D & N/D & N/D & N/D & N/D \\
Rk1 & 0.092 & 0.045 & 0.013 & 0.059 & 0.026 \\
Rg5 & 0.245 & 0.12 & 0.051 & 0.111 & 0.057 \\
Total & 4.881 & 1.462 & 1.05 & 2.148 & 1.022 \\
\hline RGF 5 & & &
\end{tabular}

RG8F0: steamed $8 \mathrm{~h}$ and dried ginseng, RG8F1: steamed $8 \mathrm{~h}$ and dried and fermented with Leuconostoc mesenteroides red ginseng, RG8F2: steamed $8 \mathrm{~h}$ and dried and fermented with Lactobacillus sp. MEI 823 red ginseng, RG8F3: steamed $8 \mathrm{~h}$ and dried and fermented with Saccharomyces cerevisiae red ginseng, RG8F4: steamed $8 \mathrm{~h}$ and dried and fermented with Lactobacillus paracasei red ginseng

로서 고온에서 증삼 할 때 생성된다(Park 등, 2003). 현재 건강 기능식품공전에는 홍삼 식품의 $\mathrm{Rg} 1$ 과 $\mathrm{Rb} 1$ 의 함량이 $0.8-34 \mathrm{mg}$ $\mathrm{g}$ 으로 설정되어 있으며 액상홍삼차에서는 $\mathrm{Rg} 1, \mathrm{Rb} 1, \mathrm{Rf}, \mathrm{Rh}$ 가 확인되어야 한다고 규정되어 있다(Kim 등, 2013).

홍삼이 약리 효능을 나타내는 ginsenoside는 장내의 미생물에 의해 분해되어 compound $\mathrm{K}$, ginsenoside Rh2 등의 대사물로 전환되며 이들은 혈액내로 흡수됨으로서 약효가 나타나게 된다. 또한 반드시 경구 투여되어 장을 거치면서 장내 세균총의 대사 를 받아야 약리 활성을 나타낸다. 장내세균의 대사를 살펴보면 protopanaxadiol계 화합물인 ginsenoside $\mathrm{Rb} 1, \mathrm{Rb} 2, \mathrm{Rc}$ 등은 ginsenoside $\mathrm{F} 2$ 를 거쳐서 compound $\mathrm{K}$ 로 대사되는데 이러한 반 응은 장내 세균인 Bacteroides 속, Fusobacterium 속, Provetella 속 균주 등이 촉매로 쓰이며, 또한 Protopanaxatriol 계 화합물
인 ginsenoside $\operatorname{Re}, \operatorname{Rg} 1, \operatorname{Rf}$ 등은 위의 균주들에 의해 ginsenoside Rh1 또는 F1로 대사되고 protopanaxatriol로 대사된다(Bae 등, $2000 ; 2002)$. 이는 인삼이 사람마다 효능 차이를 나타내는데 가 장 중요한 이유이다. 개개인의 장내 환경이 모두 다르고, 장내 세균 종 역시 모두 다르기 때문에 세균의 종류에 따라 인삼사 포닌을 대사시킬 수 있는지 없는지가 결정된다. 실제로 전체 검 사 대상 중에서 인삼사포닌을 대사시키는 사람은 전체 $20 \%$ 정 도라고 한다(Hasegawa 등, 1997).

발효 홍삼은 이와 같은 문제점을 해결 할 수 있는 제조방법 이다. 유산균이나 효모 등의 균주로 발효를 시켜 ginsenoside 등 을 미리 분해시킨 대사물을 섭취함으로서 생리활성을 보다 잘 나타낼 수 있게 된다(Kim 등, 2009). 홍삼은 특유의 성분인 ginsenoside $\operatorname{Rg} 3$ 를 통해 활성산소의 생성을 저해함으로서 세포 가 손상되는 것을 막고 이로 인해 각종 항산화 효과들이 나타 나게 된다. 이는 항암제 투여 시 일어나는 여러 가지 활성산소 로 인한 부작용들을 줄이는 것에도 적용될 수 있다.

Cisplatin은 1세대 항암제로서 여러 부위의 암에 광범위하게 쓰이고 있다(Pabla와 Dong 2008). Cisplatin으로 인해 신장독성 이 생기는 원인은, 약제가 신장에 집중적으로 축적됨으로써 투 여 용량에 비례하여 심화되기 때문으로 알려져 있다(Safirstein 등, $1984 ; 1986)$. 최근에는 cisplatin 신독성의 기전을 염증반응 으로 해석할 수 있는 실험적 증거들이 밝혀지면서 TNF- $\alpha$ 의 중 요성도 부각되고 있다(Ramesh와 Reeves 2002). cisplatin은 활 성산소를 과도하게 생성하여 신장세포 손상을 일으키게 되는데, 활성산소는 NF- $\mathrm{NB}$ p 65 를 활성화 시키고, 이로 인해 염증인자 들(iNOS, COX-2, TNF- $\alpha, \mathrm{IL}-6)$ 의 전사가 촉진되며, 이는 $\mathrm{NO}$ 를 생성시킨다. 또한 $\mathrm{NO}$ 가 필요이상으로 생성되었을 때 혈관 확장, 염증반응에 의한 세포사멸로 인해 조직손상까지 일어나게 된다(Moncada 등, 1991; Storck 등, 1994).

Cisplatin의 부작용을 줄이기 위해서 먼저 활성 산소의 억제 가 우선이기 때문에 본 실험에서는 시료들의 먼저 항산화 효과 를 알아보고 가장 항산화 효과가 높은 시료를 선정하였다. 발 효균주는 F1은 Leuconostoc mesenteroides는 젖산균으로서 김치 발효 초기에 생육되는 균이다. F2는 Lactobacillus sp. MEI 823 으로, 가바 생성을 돕는 우수 젖산균이며 역시 김치젖산균 이다. F3는 Saccharomyces cerevisiae으로서 맥주 효모균이고 F4는 Lactobacillus paracasei로서 유산균 변이주이다. 총 4가지 균주로 백삼과 증숙된 홍삼을 발효시켰고, $\mathrm{pH}$ 를 측정하여 발효 진행을 확인하였다. 성분검사를 위한 1 차 발효는 액상발효를 하 였고 동물실험에 필요한 시료는 2 차로 고형발효를 하였다.

성분검사 결과 백삼에 비해서는 증숙 과정을 거친 홍삼이 성 분이 대체적으로 높게 나왔고, 또한 증숙 시간이 길수록 높아

Table 8. Body weight, food intake and kidney weight

\begin{tabular}{|c|c|c|c|c|c|}
\hline \multirow{2}{*}{ Group } & \multicolumn{3}{|c|}{ Body weight } & \multirow{2}{*}{$\begin{array}{l}\text { Food intake } \\
\text { (g/day) }\end{array}$} & \multirow{2}{*}{$\begin{array}{c}\text { Kindey weight } \\
\text { (mg/g body weight) }\end{array}$} \\
\hline & Initial $(\mathrm{g})$ & Final $(\mathrm{g})$ & Gain (g/4 days) & & \\
\hline $\mathrm{N}$ & $32.7 \pm 0.5$ & $34.4 \pm 0.7$ & $1.7 \pm 0.3$ & $5.5 \pm 0.3$ & $16.8 \pm 0.2$ \\
\hline Veh & $32.7 \pm 0.5$ & $34.2 \pm 0.5$ & $1.5 \pm 0.2$ & $5.4 \pm 0.3$ & $17.2 \pm 0.3$ \\
\hline RG0F0 & $32.7 \pm 0.4$ & $33.3 \pm 0.7$ & $0.7 \pm 0.3 *$ & $4.9 \pm 0$ & $16.9 \pm 0.3$ \\
\hline RG8F3 & $32.7 \pm 0.4$ & $33.2 \pm 0.6$ & $0.6 \pm 0.3$ & $5.3 \pm 0.2$ & $16.7 \pm 0.4$ \\
\hline
\end{tabular}

N: Normal mice, Veh: Vehicle treated cisplatin mice, RG0F0: RG0F0-treated cisplatin mice, RG8F3: RG8F3-treated cisplatin mice. Significance: $* p<0.05$ vs. vehicle treated cisplatin mouse values 

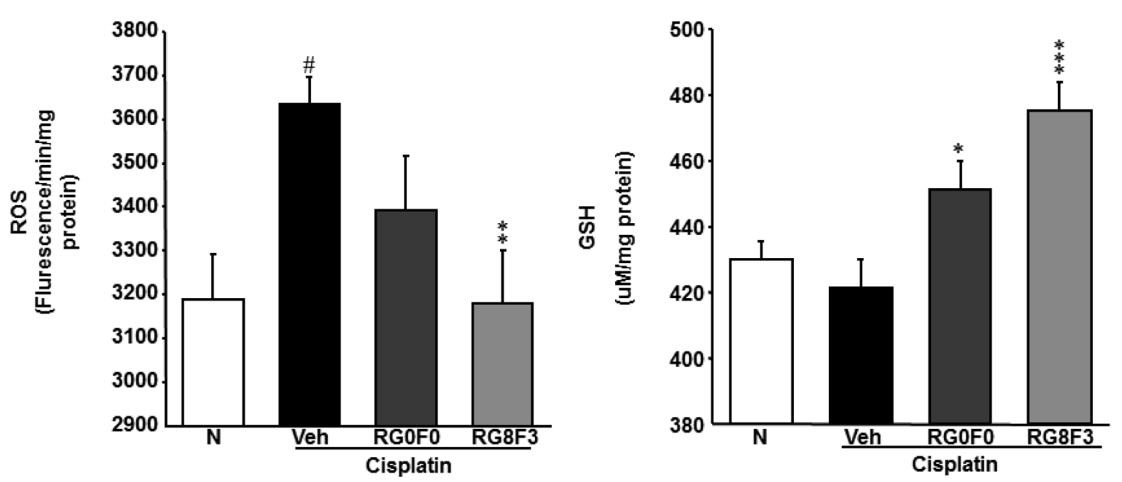

Fig. 2 Oxidative stress-related biomarkers in the kidney. N: Normal mice, Veh: Vehicle treated cisplatin mice, RG0F0: RG0F0- treated cisplatin mice, RG8F3: RG8F3-treated cisplatin mice. ${ }^{\#} p<0.05$ significantly different from the normal mice group. ${ }^{*} p<0.05,{ }^{* *} p<0.01$, and ${ }^{* * *} p<0.001$ significantly different from the vehicle treated and cisplatin induced mice group
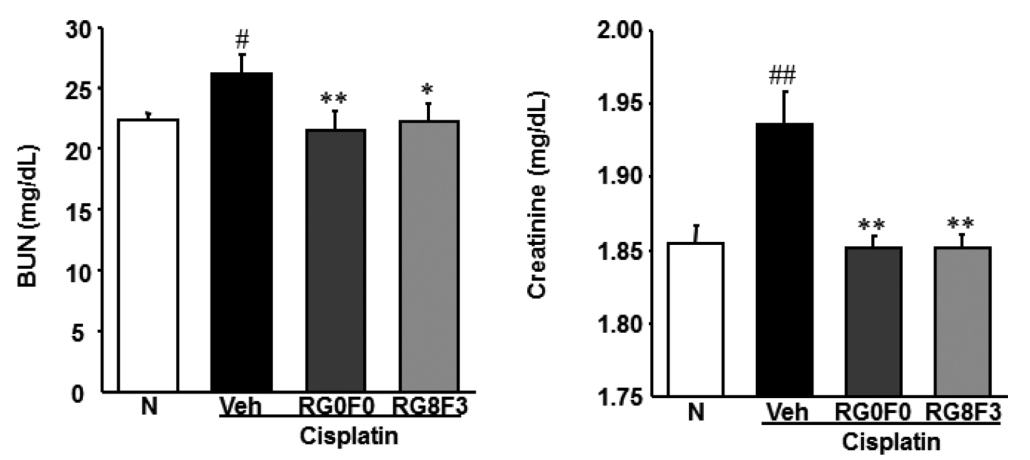

Fig. 3 BUN and creatinine in the serum. N: Normal mice, Veh: Vehicle treated cisplatin mice, RG0F0: RG0F0-treated cisplatin mice, RG8F3: RG8F3treated cisplatin mice. ${ }^{\#} p<0.05$ and ${ }^{\# \#} p<0.01$ significantly different from the normal mice group. ${ }^{*} p<0.05$ and ${ }^{*} p<0.01$ significantly different from the vehicle treated and cisplatin induced mice group

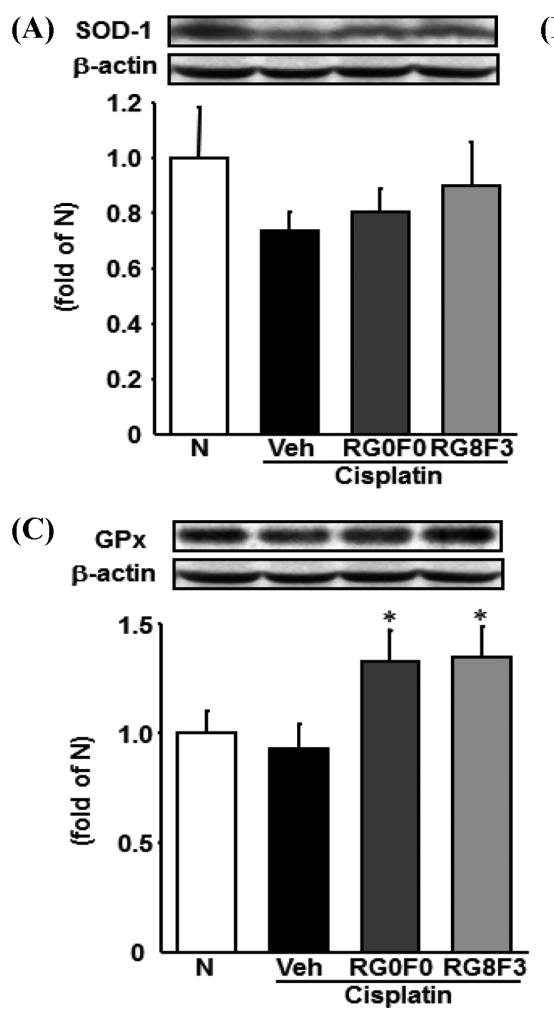

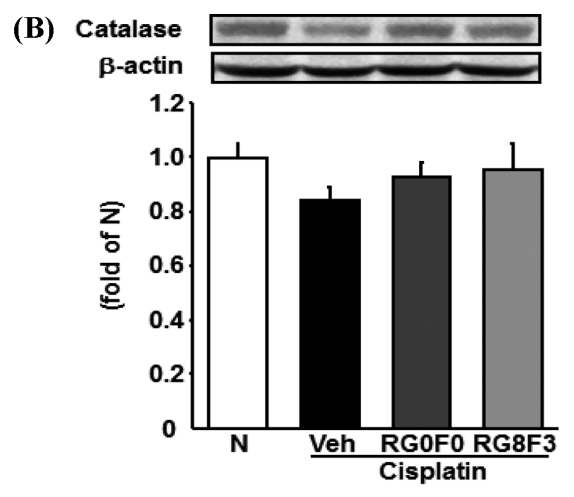

Fig. 4 Expressions of antioxidant enzymes-related protein in the kidney. $\mathrm{N}$ : Normal mice, Veh: Vehicle treated cisplatin mice, RG0F0: RG0F0treated cisplatin mice, RG8F3: RG8F3-treated cisplatin mice. ${ }^{*} p<0.05$ significantly different from the vehicle treated and cisplatin induced mice group 

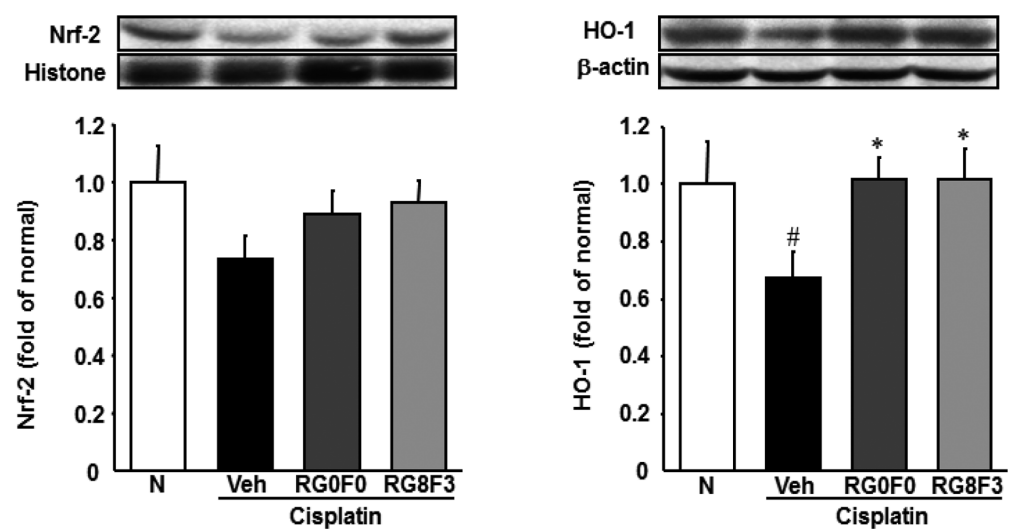

Fig. 5 Expressions of antioxidant enzymes-related protein in the kidney. N: Normal mice, Veh: Vehicle treated cisplatin mice, RG0F0: RG0F0-treated cisplatin mice, RG8F3: RG8F3-treated cisplatin mice. ${ }^{*} p<0.05$ significantly different from the normal mice group. ${ }^{*} p<0.05$ significantly different from the vehicle treated and cisplatin induced mice group

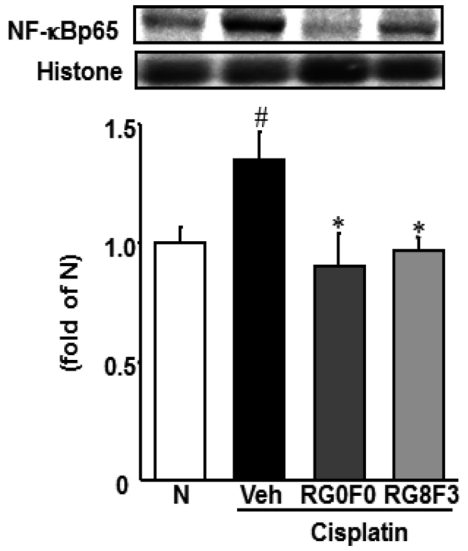

Fig. 6 Expression of inflammtion-related proteins in the kidney. N: Normal mice, Veh: Vehicle treated cisplatin mice, RG0F0: RG0F0treated cisplatin mice, RG8F3: RG8F3-treated cisplatin mice. ${ }^{*} p<0.05$ significantly different from the normal mice group. ${ }^{*} p<0.001$ significantly different from the vehicle treated and cisplatin induced mice group

지는 경향을 보였다. 그러나 발효한 건삼과 발효한 홍삼은 발 효하지 않은 홍삼에 비하여 성분 함량이 떨어지는 것을 확인할 수 있었다. 이는 건삼에서는 고온에 의해 홍삼이 되면서 생성 되는 진세노사이드 성분이 많아지지만, 발효를 거치게 되면 기 존의 성분들이 미생물에 의해 분해가 되면서 compound $\mathrm{K}$, ginsenoside $\mathrm{Rh} 2$ 등의 대사물로 바뀌기 때문에 기존 성분은 감 소되는 것으로 보인다(Bae 등, 2004). 백삼과 발효 홍삼간의 항 산화 실험 결과를 살펴보면, DPPH radical 소거능은 증숙과 발 효를 거치지 않은 건삼보다 증숙 후 발효를 시킨 발효홍삼이 균주에 상관없이 대체적으로 항산화 효과가 더욱 뛰어난 것을 알 수 있었다. 그러나 ABTS radical 소거능에서는 발효는 하지 않고 증숙만 거친 홍삼이 가장 소거능이 높았다.

증숙과 발효를 끝낸 시료들 중에서 성분검사와 항산화 실험 을 통해 최종 동물실험에 사용할 시료를 결정하였다. 성분검사 를 살펴보면 수삼의 증숙 시간에 따라 총 사포닌 양이 많아지 는 것을 알 수 있었다. 이를 종합하여 $\mathrm{RG} 0 \mathrm{~F} 0$ 와 $\mathrm{RG} 8 \mathrm{~F} 3$ 을 동 물실험에 사용하였다.
동물실험 결과, 체중과 식이섭취량 및 신장무게는 정상군과 비교하였을 때 체중증가에만 유의성 있는 결과를 보였고 식이 섭취량 및 신장무게는 유의적인 차이를 보이지는 않은 것으로 보아 약물투여는 동물의 상태에 크게 영향을 주지 않는 것으로 보였다. 신장 기능의 표준 생화학적 표지물질인 혈청 내 $\mathrm{BUN}$ 과 creatinine의 양을 분석하여 기능변화를 확인해본 결과, 정상 군에 비해 대조군의 BUN과 creatinine 수치는 증가하였으나 백 삼과 발효홍삼 투여 시 대조군에 비해 유의성 있게 적은 증가 경향을 보였다.

위의 결과들을 종합해보면, 건삼과 발효홍삼은 모두 항산화 효과가 있었으며, 특히 RG8F3은 cisplatin으로 유도시킨 신장손 상에 대해 $\mathrm{ROS}, \mathrm{SOD}$, 그리고 catalase를 감소시켰고 $\mathrm{HO}-1$ 과

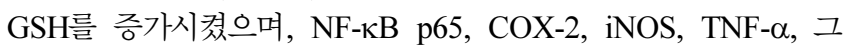
리고 $1 \mathrm{~L}-6$ 를 모두 감소시킴으로 인해 신장손상을 줄이는 효과 를 나타낸다고 볼 수 있었다. 이는 실제 조직학적인 결과에서 도 신손상으로 인한 변형이 거의 없었고 정상에 가까울 정도로 신장손상이 억제되는 것으로 나타났으며 이로 인해 발효홍삼은 cisplatin으로 유발되는 신 손상 예방에 유의한 효과를 보이는 것으로 생각된다. 그러나 발효 홍삼의 어떤 성분이 어떤 작용 으로 인해 효과를 내는 것인지는 아직 밝혀진 바 없으므로 더 욱 자세한 연구가 필요한 것으로 사료된다.

\section{초 록}

홍삼은 인삼을 찌고 말리는 과정을 거쳐 제조한 것으로 많은 약리 및 생리활성이 알려져 있다. Cisplatin은 항암제로 사용되 고 있으나 부작용으로 골수억제, 위장관계독성, 신경독성, 신독 성 등이 보고되어있다. 특히 cisplatin이 신장에 집중적으로 축 적됨으로써 투여환자의 25-30\%에서 신장독성이 유발된다. 따 라서 본 실험에서는 발효홍삼을 이용한 cisplatin의 부작용인 신 독성예방효능을 확인하고자 하였다. 시료에 따른 $\mathrm{DPPH}$ 와 $\mathrm{ABTS}$ 라디칼소거능을 실험 결과 $\mathrm{RG} 8 \mathrm{~F} 3$ 에서 가장 우수한 소거능을 확인하였고 따라서 RG0SF0와 RG8F3 간의 비교실험이 가능할 것으로 사료되었다. 동물실험은 정상군, 대조군, RG0SF0 투여 군 및RG8F3 투여군 4그룹으로 나누었다. 약물투여군은 $200 \mathrm{mg} /$ 

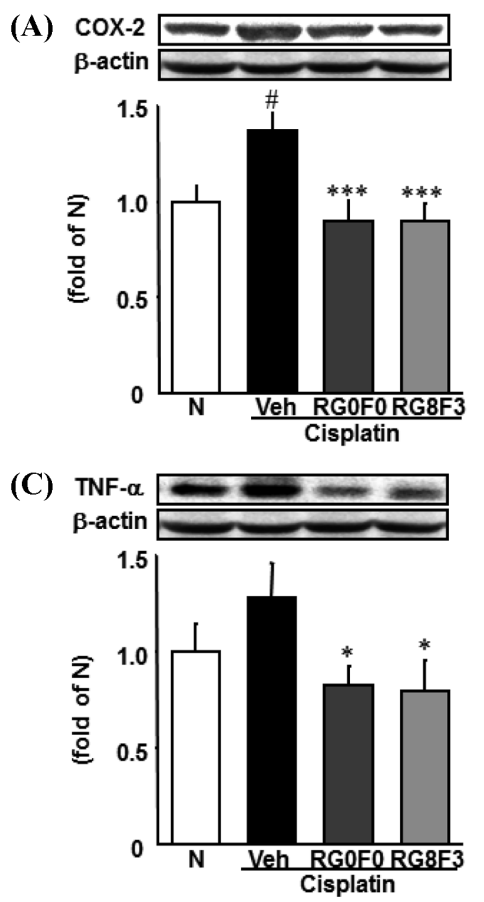

(B) inOs
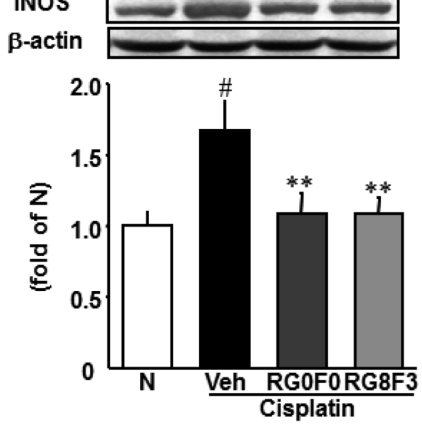

(D) IL-6 Treseres

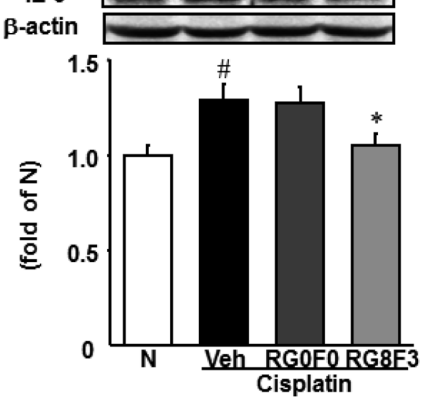

Fig. 7 Expressions of inflammation-related protein in the kidney. N: Normal mice, Veh: Vehicle treated cisplatin mice, RG0F0: RG0F0-treated cisplatin mice, RG8F3: RG8F3-treated cisplatin mice. ${ }^{\#} p<0.05$ significantly different from the normal mice group. ${ }^{*} p<0.05,{ }^{* *} p<0.01$, and ${ }^{* * *} p<0.001$ significantly different from the vehicle treated and cisplatin induced mice group

(A)

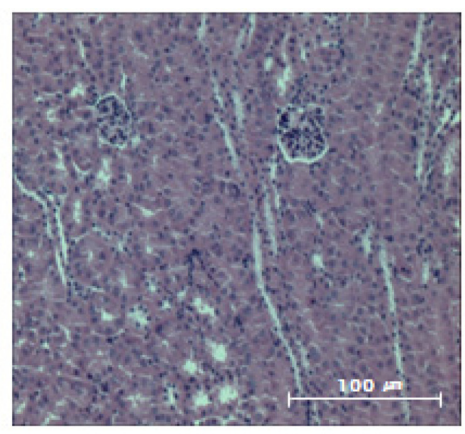

(C)

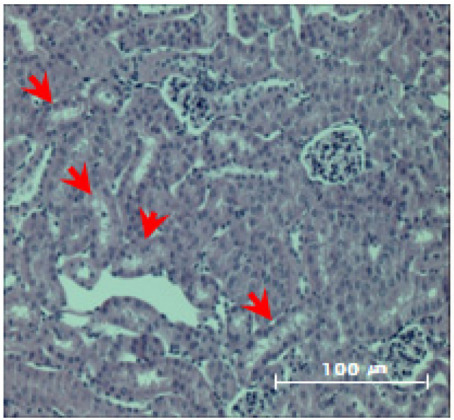

(B)

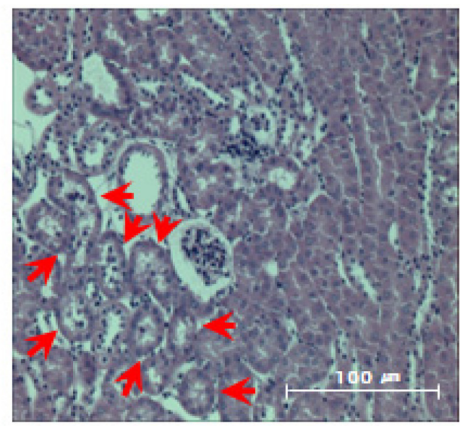

(D)

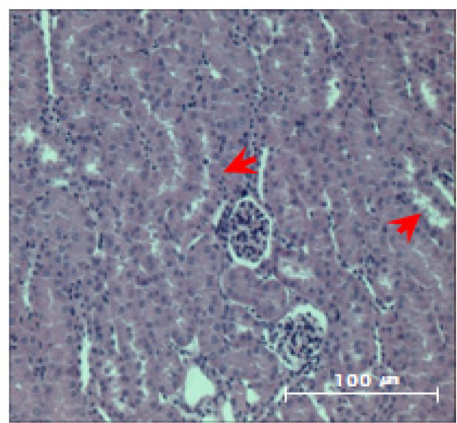

Fig. 8 Effect of RG0F0 and RG8F3 on the histopathological change renal tissues of cisplatin treated mice. Renal tissues were stained with H\&E (Original magnification $\times 200$ ). The red arrowheads indicate the destruction of renal tubular cells. (A) Normal mice, (B) Vehicle treated cisplatin mice, (C) RG0F0-treated cisplatin mice, (D) RG8F3-treated cisplatin mice 
$\mathrm{kg} / \mathrm{day}$ 의 농도로 4 일간 투여한 후,cisplatin은 $20 \mathrm{mg} / \mathrm{kg}$ 으로 대 조군 및 약물투여군에복강주사하였다. RG8F3 투여한 결과 대 조군과 비교하여 $\mathrm{GSH}$ 의 수치는 증가하였고 $\mathrm{ROS}, \mathrm{BUN}$, creatinine 및 염증인자들의 감소를 보였다. 조직학적 결과에서 도 신손상으로 인한 변형이 거의 없었다. 결론적으로 발효홍삼 은 cisplatin으로 유발되는 신 손상 예방에 유의한 효과를 보이 는 것으로 사료된다.

Keywords 발효 - 신독성 - 항산화 - 홍삼 - cisplatin

\section{References}

Ahn DW, Kim SR, Ha DH, Kim SH (2007) Mechanism of Amelipration of Cisplatin Nephrotoxicity by Procaine Treatment in Mice. Korean J Anesthesiol 52: 318-327

Appenroth D, Frob S, Kersten L, Splinter FK, Winnefeld K (1997) Protective effects of vitamin $\mathrm{E}$ and $\mathrm{C}$ on cisplatin nephrotoxicity in developing rats. Arch Toxicol 71: 677-683

Bae EA, Han MJ, Choo MK, Park SY, Kim DH (2002) Metabolism of 20(S)and 20(R)-ginsenoside Rg3 by human intestinal bacteria and its relation to in vitro biological activities. Biological \& Pharmaceutical Bulletin 25: $58-63$

Bae EA, Han MJ, Kim EJ, Kim DH (2004) Transformation of ginseng saponins to ginsenoside Rh2 by acids and human intestinal bacteria and biological activities of their transformants. Archives of pharmacal research 27: 61-67

Bae EA, Park SY, KIM DH (2000) Constitutive. BETA.-Glucosidases Hydrolyzing Ginsenoside Rb1 and Rb2 from Human Intestinal Bacteria. Biological and Pharmaceutical Bulletin 23: 1481-1485

Baek SH, Piao XL, Lee UJ, Kim HY, Park JH (2006) Reduction of cisplatininduced nephrotoxicity by ginsenosides isolated from processed ginseng in cultured renal tubular cells. Biological and Pharmaceutical Bulletin 29: 2051-2055

Davis CA, Nick HS, Agarwal A (2001) Manganese superoxide dismutase attenuates cisplatin-induced renal injury: importance of superoxide. J Am Soc Nephrol 12: 2683-2690

Gandara DR, Perez EA, Phillips WA, Lawrence HJ, DeGregorio M (1989) Evaluation of cisplatin dose intensity: current status and future prospects. Anticancer Res 9: 1121-1128

Glover D, Grabelsky S, Fox K, Weiler C, Cannon L, Glick J (1989) Clinical trials of WR-2721 and cis-platinum. Int J Radiat Oncol Biol Phys 16: 1201-1204

Han SY, Yeo SH, Jeong ST, Choi HS, Baek SY, Park HY (2012) Status and Prospect of plant Fermented Liquid in Korea. Food Science and Industry 45: $31-43$

Hasegawa H, Sung JH, Benno Y (1997) Role of human intestinal Prevotella oris in hydrolyzing ginseng saponins. Planta medica 63: 436-440

Howell SB, Taetle R (1980) Effect of sodium thiosulfate on cisdichloro diammineplatinum (II) toxicity and antitumor activity in L1210 leukemia. Cancer Treat Rep 64: 611-616

Ju SM, Kim SH, Kim YM, Jeon BH, Kim WS (2013) Machanism of Cisplatin-induced Apoptosis and Bojungbangam-tang-mediated Antiapoptotic Effect on Cell Proliferation in Rat Mesangial Cells. Korean J Oriental Physiology \& Pathology 27: 43-48

Jung KW, Won YJ, Kong HJ, Oh CM, Cho HS, Lee DH, Lee KH (2015) Cancer Statistics in Korea: Incidence, Mortality, Survival, and Prevalence in 2012. Cancer Res Treat 47: 127-141

Kim DG, Kim KJ, Ju SM, Kim YI, Choi HS, Keum KS, Kim WS, Gao YA, Jeon BH (2003) Protective effect of Ganopoly and Ganopoly/C+ on nephrotoxicity induced by cisplatin in rats. Korean J Oriental Physiology
\& Pathology 17: 316-325

Kim HG, Kim KY, Cha CJ (2007) Screening for ginsengfermenting microoragnisms capable of biotransforming ginsenosides. Kor J Microbiol 43: 142-146

Kim HJ, Kwak IA, Kim HJ, Ahn JS, Son YB (2013) A Study on the Amendment Scheme of Ginsenoside Content Standard Regulation for Red Ginseng Products in Korea. Journal of Food Hygiene and Safety 28: 24-30

Kim HJ, Seo MH, Lee EK, Cho HE, Choi YH, Lee KN, Chong MS (2009) Effect of Fermented Red Ginseng Extracts on Physiological Activity and Blood Glucose Level in Streptozotocin Induced Diabetic Rats. Korean J Oriental Physiology \& Pathology 23: 1087-1094

Kim JY, Kim CH (2014) Effect of Zizyphi Spinosae Extract on Cisplatin and t-Butylhydroperoxide Induced Acute Renal Failure in Rabbits. Journal of Life Science 24: 777-783

Krarup-Hansen A, Helweg-Larsen S, Schmalbruch H, Rørth M, Krarup C (2007) Neuronal involvement in cisplatin neuropathy: prospective clinical and neurophysiological studies. Brain 130: 1076-1088

Moncada S, Palmer RML, Higgs EA (1991) Nitric oxide: physiology, pathophysiology, and pharmacology. Pharmacological reviews 43: 109142

Nam KY (2005) The Comoarative Understanding between Red Ginseng and White Ginsengs, Processed Ginsengs (Panax ginseng C.A. Meyer). J Ginseng Res 29: 1-18

Naziroglu M, Karaoglu A, Aksoy AO (2004) Selenium and high dose vitamin $\mathrm{E}$ administration protects cisplatin-induced oxidative damage to renal, liver, and lens tissues in rats. Toxicology 195: 221-230

Nicolao P, Giometto B (2003) Neurological toxicity of ifosfamide. Oncology 65: $11-16$

Nishijo H, Uwano T, Zhong Y M, Ono T (2004). Proof of the mysterious efficacy of ginseng: basic and clinical trials: effects of red ginseng on learning and memory deficits in an animal model of amnesia. Journal of pharmacological sciences 95: 145-152

Oriana S, Bohm S, Spatti G, Zunino F, Di Re F (1987) A preliminary clinical experience with reduced glutathione as protector against cisplatintoxicity. Tumori 73: 337-340

Ozols RF, Corden BJ, Jacob J, Wesley MN, Ostchega Y, Young RC (1984) High-dose cisplatin in hypertonic saline. Ann Intern Med 100: 19-24

Pabla N, Dong Z (2008) Cisplatin nephrotoxicity: mechanisms and renoprotective strategies. Kidney international 73: 994-1007

Park CK, Jeon BS, Yang JW (2003) The Chemical Components of Korean Ginseng. Food Industry and Nutrition 8: 10-23

Park SY, Choung SY (1998) Inhibitory Effect of Schizandrin on Nephrotoxicity of Cisplatin. Korean J Environ. Toxicol 13: 125-131

Parlakpinar H, Sahna E, Ozer MK, Ozuglurlu F, Vardi N, Acet A (2002) Physiological and pharmacological concentrations of melatonin protect against cisplatin-induced acute renal injury. J Pineal Res 33: 161-166

Ramesh G, Reeves WB (2002) TNF-alpha mediates chemokine and cytokine expression and renal injury in cisplatin nephrotoxicity. Journal of Clinical Investigation 110: 835-842

Safirstein R, Miller P, Guttenplan JB (1984) Uptake and metabolism of cisplatin by rat kidney. Kidney Int 25: 753-8

Safirstein R, Winston J, Goldstein M, Moel D, Dikman S, Guttenplan J (1986) Cisplatin nephrotoxicity. American Journal of Kidney Diseases 8: 356-367

Storck M, Schilling M, Prestel R, Abendroth D, Burkhardt K, Hammer C (1994) Production of proinflammatory cytokines and adhesion molecules in exvivo xenogeneic kidney perfusion. Transplant International 7: 647649

Sutton TA, Molitoris BA (1998) Mechanisms of cellular injury in ischemic acute renal failure. Seminars in Nephrology 18: 490-497

Yoon SS (2008) Management of Hematologic Malignancies. J Korean Oncol Nurs 8: $67-75$ 